\title{
A Review on State of the Art in Flipped Classroom Technology A Blended E-Learning
}

\author{
Anwar Ali Sathio ${ }^{1}$, Mujeeb ur Rehman Shaikh ${ }^{2}$, Ali Orangzeb Panhwar ${ }^{3}$, \\ Ubaid Rehman $^{4}$,M.Afzal Sahito ${ }^{5}$ Abdullah Lakhan ${ }^{6}$ \\ ${ }^{1,2,3,5,6}$ Lab of Information Security and AI, Department of Computer Science and Information \\ Technology,Benazir Bhutto Shaheed University Lyari,Karachi, Sindh, Pakistan, \\ anwar.sathio@bbsul.edu.pk, mujeebshaikh137@gmail.com, \\ Orangzebpanhwar@gmail.com,Afzalsahito87@gmail.com, abdullahrazalakhan@gmail.com \\ ${ }^{4}$ SZABIST Karachi, Pakistan, ubaidrshaikh@gmail.com
}

\begin{abstract}
Flipped is an emerging mode of blended e-learning, as blended is mix mode of learning to enhance the skills of students, saving the time and cost either sides (students and educators). Flipped classroom is such as an e-learning blended approach in which instructions can be hovered into individual and groups, interactively to exchange and solving the assigned problems. Flipped classroom approach presents the dynamic, interactive and user's friendly environments for in class and online blended learning. This kind of mode leads students to enhance their interpersonal skills, collaborate the experiences, and innovate new horizons by mutual activities for the given problems. The flipped mode has at least four dimensions; friendly easy environment, supporting culture for learning, contents availability when offline, minimizing time cost, trained educators/professionals and reducing repetition of learning content's cost. In Flipped model of learning, first students go to seeking the exposure of problems by visiting the contents, materials, videos and other materials before getting in the classroom in person, fully aware to share or inquire the problem related matters in the class, its inverse approach against traditional institutional learning model. This is very effective mode of learning for activity based and assignment-based learning strategies prior commencing class, fruitful feedback can be shared and reducing the tutorial part.
\end{abstract}

Key words: E-learning, Flipped Class room, Blended Learning

\section{Blended Learning}

The term blended was coined in the market of technology at the end of decade 90, due the huge and emerging concepts making new trends through collaborative and individual learnings[21] and this change of approach having lot of potential to engage the stack holders, and educators, minimizing the obstacles relating to time, place, paths etc.

Definitions
In the early days, the term "blended learning" according to [21] it was a mixture of technology and educational means only. In the early stage of this approach "blended Learning" may be just the internet accessibility to the students for like instructional means [21]. Another view come out in 2003 when Procter[54] explained that the different mode of delivery for learning relates to blended learning, its somehow little clear to the approach "blended"[54]. Another dimensional view of the definition by[29] was that it's a mix system of physical appearance and computer supporting elements for learning[29] by virtue of this definition it is further some extent clear that the system having two mixed modes at the same time for deliverance of the lectures.

As described by[60] made clear picture about the definition of the concept "blended" that just a formal system of education but having the delivery mode in mixed integrated structure some part of lecture in the class, some part of the lecture out of the class, permitting students by flexibility of time, space, pace and away from classroom physically[60,66]. Further the "blended " approach explained by adding the features, like interactive and collaborative learning approach, meant that some part must has time allocation for interactive session with teacher and also interactive session with students groups too when needed for collaboration study time, group studies, discussions, and solving group assignments [44].

\section{Blended learning Models}

The blended learning models may derive into three major categories:

1. Skill-driven, some initially required valued skills of the students with supportive role of teachers

2. Attitude-driven, provision of positive environment of behaviors, between groups, individuals centrally.

3. Competency-driven, observation of expert's knowledge for level best learning outcomes[65].

The further basic six models extended to 12 models introduced in the blended learning approach:

1. F2F-Model, face to face, presence in classroom, additionally supporting online art of learning too.

2. Rotation-Model, replacing classroom by online in routine for acquiring the knowledge and learning. 
Anwar Ali Sathio et al., International Journal of Emerging Trends in Engineering Research, 9(7), July 2021, 973 - 982

3. Flex-Model, in routine online class customization, but when required teacher may also provide in person available for F2F classroom environments.

4. Lab-Model, when an additional supplementary study required to complete the traditional course of study by online availability of teacher.

5. Self-Blend-Model, an opportunity for getting additional capability regarding courses, this may also support on students demand and choice.

6. Virtual-Model , solo pattern, online single mode but occasionally sometimes getting physically visiting the class for analysis and assessment of the student learning[65].

The above six models re-designed and merged into four composed models, rotation, flex, self-blend, and virtual models respectively. As the important resect to rotation model is an example of "Flipped Classroom"[1].

\section{Trending approaches in the hybrid or Blended E-Learning concepts:}

There are 12 blended e-learning models discovered in current literature listed below:

1. Station Rotation- Blended Learning

2. Lab Rotation- Blended Learning

3. Remote- Blended Learning (also referred to as Enriched Virtual)

4. Flex - Blended Learning

5. The 'Flipped Classroom' - same as remote blended learning.

6. Individual Rotation -Blended Learning

7. Project-Based- Blended Learning

8. Self-Directed- Blended Learning

9. Inside-Out -Blended Learning, Outside-In- Blended Learning

10. Supplemental- Blended Learning

11. Mastery-Based- Blended Learning

The Blended learning approach is hybrid approach, another way it known as alternate or rotational approach, all researchers agreed that it's an instructor-centered approach, controlled by instructor through internet and physically as well, just technology mechanism provides the support additionally ranging towards the innovations and emerging concepts of learning and teaching [1].

The full potential of blended learning reached when it moved towards from teacher to learner centered in design, giving importance to collaboration, interaction, building knowledge and interpersonal skill development for sustainable development, so focus also shifting from just technology to learning as well $[24,52,59]$. Actually, it's a change from conventional to active flipped classroom, dual respond observed in the sense of usability manner [68] .

Blended learning design features for deeper study:

Research findings in keeping with[48]for usability mixing learning ideas, it had been discovered and noted the progressive and positive impacts on the following key components:
1. Communication tools

2. User friendly and simple to access

3. well-structured in an exceedingly clear and comprehendible manner

4. On-line resources for alternative course units in future

5. helpful as a learning resource

6. Organized however they might work along in study throughout the face-to-face conferences

7. At the psychological feature level, learners interacted with content

8. Got course objectives and structure introduced throughout the face-to-face sessions

According to research study[48,80] it was found the progressive approach towards the blended adoption of model and its impacts, these dimensions explored below in a research study:

1. The technology quality rated at 69 percent,

2. the availability........ 72 percent,

3. quality resources... 68 percent,

4. right content necessary for study .........71 percent

5. the email exchanges for needed information 63.4 percent

6. chats for essential information .69 percent

7. Internet reliability at .66 percent with a speed considered

8. Averagely good to facilitate online activities .63 percent[48].

\section{Blended Learning moving towards Flipping concepts:}

The blended learning is further when deeper classified into variety of emerging concepts, the Flipped classroom ,a branch of blended learning[18], such an extension of hybrid, rotation, or alternate concepts with some extent an additional feature, as collaborative and interactive elements. If the Massive Open Online Courses (MOOCs), we consider as E-learning concept, comparing with it, such way is just missing an element of interaction[69], According to [34] that Flipped the classroom learning easily described additionally face to face with the help of live interactive instruction session with teacher to increase the learning outcomes.

\section{Flipped learning and tertiary education}

According to $[36,37,38,79]$ it is an extension of blended scope learning, an enquiry supported by learning instruction and tools, with multiple factors as flexibility, active engagements often in learning as compare to blended passive concepts[36,37,38].

The concept of "Flipped classroom" was also expressed as "Inverted Classrooms" coined by some researchers[5] in 2000.

The Flipped model is a concept of homework and off-class activities[3]and a model when to make learners taking responsibilities in a flexible environment of learning[14,22]. Flipped classroom model provide an environment which include Project based or real-world practices for learners in order to learn the subject better at class time [58]. The 
Anwar Ali Sathio et al., International Journal of Emerging Trends in Engineering Research, 9(7), July 2021, 973 - 982

learning by flipped classroom through course videos, digital resources of text reading, meetings with peers, groups in interactive online session, available resources all time when they want, getting involved interactively more than conventional model of learning, objective to provide best authentic contents and information to learners[36,37,38]. The name of flipped revealed it by pronouncing as Inverted classroom in 2000 by faculty of Miami University[45]. The learners getting lesson by videos using necessary technologies at any time, this help their homework processing, participate in learning process[43]. The idea behind flipped classroom enforce the educators, institutions and learners that when the contents of the course studies is mostly dependent on directly to educators interactive state of learning then this is the best one choice for getting maximum outcome and highly encouraging to all sectors.

\section{Defining flipped learning}

According to the Flipped Learning Network,[20,55] described it as a teaching approach, moving instructions to individually as well as group instructions interchangeably, dynamically too. Further it explained four major foundations for flipped naive approach. FLIP are four main foundations, described as Flexible, Learning, Intentional and Professional. The flexibility environment has several dimensions such as need, spaces, learning modes, in Learning culture may also include the scope as collaborative, active, passive, place, dealing content, time and pace.

According to[58] this model acronym FLIPPED:

- F- Flexible Environments

- L- Learner-Centered Approach

- Intentional Content

- P- Professional Educators

- P-Progressive Networking Learning Activities

- E- Engaging and Effective Learning Experiences

- D- Diversified and Seamless Learning Platforms[58].

According to [64] flipped model for preschool education got more successful outcomes as compare to traditional model applications, and [39] applied it on medical students resulting more effective source of learning in medical field. It demonstrates that these flipped lecture rooms square measure enlightened by artist pedagogy and highlights the role university academics will play in facilitating their students' engagement with learning. It additionally highlights that to achieve success during this transition to a brand new mode of learning needs each a holistic institutional designing approach, one primarily based inside a coherent student learning journey model, and sustained development by a team of centralized support employees, together with technology specialists, librarians and learning designers.

Factors of Flipped Classroom:
According to[50] at least five important key factors including few other may be considered to when going to plan this mode of learning[40] are as :

a. Content shall be updated and relevant, outcome tested, and can be applied in real world,

b. Activity based, attention-model and can acquire the experience as well as knowledge by easily adopting the model themes of learning in all dimension, interactive, collaborative, and shall presenting the benefits

c. Effective and active technological resources (laptop, tablet, smartphones etc.) adoption and availability in whole processing session.

d. Positive attitudes and Reflexive approach and shall be adopting the methods of measuring response and reactions, whether it is relevant, to the goal point or not.

e. Accessibility and flexibility of time and place to all resources in home as well of the class session, this encourage and enhance the capacity of learners.

f. Additional factors may also very important to be considered.

1. Scope shall be defined according the course

2. Updated and relevance to the session of contents.

Benefits of flipped learning

The capability of students when increased by online access relating course content, will enhance the learning skills, and self-motivation and when this achieved the mode of learning flipped with active model approach[30].

Factors to be considered for designing and implementations of Flipped classroom design[69] :

1. Setting ratios for active and passive modes, as well as face to face classrooms in schedule.

2. The target-oriented groups lie in the class for Flipped approaches not all community

3. In live active mode students shall not feel isolation anyway

4. Before getting start, the Flipped classroom approach, all shall be well informed and trained new technology accessibility and navigation for total learning benefits for less capable persons.

5. The technology selection for students shall be surveyed and average and updated reliable sources and selected to maintain the gap between stack holders and technology

6. for contents availability of LMS and supporting cloud repository round the clock for students

7. Curricula also updated as well as maintain the balance according to flipped concepts

8. Testing and selection criteria for Flipped classroom shall help to motivate the student community, institutions as well as educators.

9. Educators must be fully capable, well experienced, and Up-to-date prior commencing the Flipped classroom.

Consequences or Limitation to be considered for Flipped classroom approach[69] :

1.The flexibility of learning in own pace may lead less motivation to this approach sometimes. 
Anwar Ali Sathio et al., International Journal of Emerging Trends in Engineering Research, 9(7), July 2021, 973 - 982

2.The flexibility may not integrate with contents/course/program by choice, sometimes vulnerability may occur, may lead to disaster as no one reaching in consensus due to freedom.

3. The analysis and test patterns may lead sometime confusion in dual mode of learning, either fixed ratio or rotatory; what shall be the best way to conduct for assessment. 4. The inaccessibility of resources may lead discouragements for flipped mode of learning.

5. the role of teachers very important in the flipped mode but due to overload of two different environments assessment of quizzes, tests, interactions the quality cannot be maintained consistency in long-term situation.

6. It shall not be the model for teach-test model concepts

7. The Flipping classroom concepts if increased will lead to more expenses required, in class as well as additional expenses of internet, computer and cellphones.

\section{Advantages Flipped classroom learning model:}

According to [22] some literature[33]focusing on the educators

And learners, considered the following advantages for the Flipped Classroom model:

1. Learners' freedom and flexibility towards contents when and where availability of resources make them enjoy the study.

2. Home task can be completed in class also, with interactive-plus session for detail comprehensive support by tutors to complete the tasks.

3 . The course material availability and accessibility all time

4. The maximized returning the outcomes in class session for learners as well as educators.

5. The outcomes ration results showed that model is more effective and has big potential.

6. Extra more time allocation available for this model

7. Engaged learners more time by using this model of learning

8. Extra curricula activities may not disturb the learners to catch the session passed

9. Enforce learners remain active all the time during course

10. Participatory and Collaborator approach lead them to get good results

\section{Limitations of Flipped classroom:}

There are some limitations according to researchers [63] and [33] of flipped classrooms:

1. Prepared video lectures may not fully understandable for all learners

2. Teachers burden may increase

3. Teacher if not respond properly, it will irritate the learners and outcome will not coming satisfactorily

4. Learners ill attention and non-seriousness towards new model of learning effects on outcomes

5. Monitoring the off class/flipped session for educators little hard.
6. Less privileged and capacity of learners make them unhappy

7. More cost required to this mode sometimes[58].

The usability of moderated approach active flipped learning, learner gain high-level analytical skills, in this process, learner fully involved in activity, environment encourage them to lead the position pertaining to innovative ideas and contribute there and may play an important role for object oriented solutions[13].

According to [49] active learning is learner centered concept and opportunities, it's actually the applied thoughts at high level cognitions.

The ways of learner-centered in flipped classroom, collaboration, group discussion, open ended, case studies, group assignment, object-oriented based learning, and problem solving task etc. all these will be more important for learners before going into practical world[56].According to [3] lot of variety design cases applied for course content in the flipped model, some researchers refer to complete change of design in contents environment[15], whereas some also suggests starting with normal position of contents gradually shifting and when and where required moments for flipping [7,8,9,31,32]. Flipped learning is very popular in text-oriented contents in the literature as described by $[10,16,57]$.

\section{Facilitating flipped learning}

When flipped classrooms are well designed and effectively facilitated, the following benefits for students are documented in the literature:

The benefits of flipped classroom, can be described into following ways:

1. Learning performance can be enhanced [19].

2. Learner capable to innovations[61].

3. Interpersonal Skills highly improved[17].

Some appropriate suggestions for learners when adopting flipped model:

1. Issue warnings if learners not focusing in class activities, focusing only in flipped mode and do not complete the class preparation vice versa.

2. Duration and gap between face to face and flipped session shall be well defined and composed, learner may ready to take on the session well [8].

3. both active and face to face modes of quizzes shall be included with open opportunity before other activities[51].

4. Encourage, award incentives for getting task complete before coming in to the class, by providing the reports, assignments, group talks written reports[42,67].

5. class time may describe fully by learning outcome[53].

According to [69] the advantages may be extended into the Flipped classroom approach:

1. This will enhance the learning outcomes ration with increasing the skills and sustainable development. 
Anwar Ali Sathio et al., International Journal of Emerging Trends in Engineering Research, 9(7), July 2021, 973 - 982

2. This also increase the collaborative learning outcomes, a positive impact on oneself motivational for IT skills and literacy.

3. This encourage the students as well as teacher for capacity of knowledge and personal development

4. maximize the learning opportunities in flexible modes, losing control obstacles in time, place and pace constraints

5. feedback helps to improve the learning standards

6. increase the critical analysis capacity of both role players in the model approach

7. collaborative learning approach integrate all with equal opportunity and knowledge enhancement

8. Professor/teacher available after class for further instructions, good impact on students psychologically as well as academically.

9. After session, contents, and information available for little late students, can catch the assed information, can complete it without any problem.

10. Both modes active and passive learning assessment can easily be analyzed separately.

According to the researchers[2] challenges do not be ignored in the flipped classroom trend:

These challenges may be as:

- Innovative idea may lead not fully implemented into Flipped model

- Getting problems with new tech during integrations of flipped model

- Increasing the extra burden of employment cost

- Increase time consumptions in preparations of videos

Terms used in Flipped classroom interchangeably:

1. Traditional teaching; classroom, face to face practice and homework some activity.

2. Alternative teaching: transferring mode from traditional to emerging technology and methods to help learners.

3. Critical thinking: capacity increased at higher levels to solve challenging tasks.

4. Student growth: learner improves skills in alternative flexible environment.

5. Project-based activities; object oriented collaborative and flexible environment helps to find the solution practically and mutually; this provoke higher-level thinking.

The teacher's role in the flipped modeled classroom:

Teacher plays very effective and important role to carry this process" Flipped classroom", all burden shift to teacher, making learner free from worries, converting teacher-centered to learner -centered moderator approach in the Flipped model of learning, "most visible but least critical step" [35].

Learners led by teachers' instructions according to:

1. Before coming in the class, students viewed the lecture video, may other content also upload at LMS.

2. Instruction relating to video lecture must be circulated among all for easy understanding of the video lectures.
3. Task given to students must be comprehensive to solve at home and collaboratively[11,71].

4. In the next day, in class teacher clarify the all misconceptions, homework may carry out in the classroom activity with interactive and collaborative manner.

The Flipped classroom may be classified in three types[4]: 1. Traditional flip

In the concept homework given in the video -lecture, not more than 20 minutes the video, a necessary required information to start the topics of study in class, helps students to understand, next day teacher may enquire about the viewed lecture and understandability of students as well in the class. Traditional flip model observed very effective flipping the classroom $[36,37,38,72]$.

\section{In-class flip}

Here in-class Flip concept remain same but little difference of no-homework activity exists, all swapped, alternate arts of study scheme carried out in the class only.no repetition, once deliverance, just a traditional superior role, in the class flip, move to any station and clear misconceptions once only [27].

\section{Mastery flip}

According to [6] individuality concept in doing the all activities in a smooth pace. The task given in a precise manner to learners to gain the required objective of the tasks with time liberty flexibility. After conclusion of task, learner describe it before teacher, how it completed.

When the completed task reached at sufficient standard level, learner may forward to next sub-session of session.

As known by [6], the mastery flip has at least 3 main components:

1. Group or single learning environment, where educator make assessment and may analyze the learning outcome.

2. Learners list the objective activities with free facility mode of their own choice in all dimensions of resources usability

3. The demonstration of given task within the assigned range of objectives so that can be assessed and evaluated well for outcomes.

\section{Important roles in Flipped Classroom}

There are two active roles being involved in the flipped classroom: A teacher and a student.

These roles either in active or passive modes of implementations, can be explained below

Active roles and passive roles of the flipped classroom approach:

1. Active role : Students, Teacher

2. Passive role: IT staff, Networks, Clouds, LMS etc.

The process of design and development for flipped classroom was distributed as follows:

1. Content, creation and preparation.

2. Environment suitable through platform accessibility round the clock.

3. Activity based on resultant outcomes in class, face-to-face by students, in groups, interactively. 
Anwar Ali Sathio et al., International Journal of Emerging Trends in Engineering Research, 9(7), July 2021, 973 - 982

4. Final exam ready appearance by utilizing all mandatory sources and activities to accomplish the assigned tasks during sessions.

Strategies maintaining; student engagement through the course requires four strategies in blended learning [62]:

1. Clear content structure

2. Clear, unambiguous instructions and guidelines in assessment

3. Challenging, authentic tasks

4. Timely, elaborated feedback

Digital tools to support blended e-learning models as well as flipped classroom learning[23]:

The digital resources for hybrid mode of learning may be classified as:

1. Open sources of hybrid/flipped learning.

2. Dedicated sources of hybrid/flipped learning; LMS, CMS, etc.

Digital tools supporting the blended-flipped learning [23,73,74]:

1. Blogs Learning and teaching strategies.

2. Live Internet streaming Learning and teaching strategies :

3. Web/video conferencing Learning and teaching strategies

4. Twitter Learning and teaching strategies

5. Screen capture/recording Learning and teaching strategies

6. Open education resources Learning and teaching strategies

The Flipped classroom -six steps:

According to [70] steps relating to the how a methodology can be implemented in the flip model :

The required steps when pre-flipping a classroom implementation include:

Step 1: Setting standard task; simple, easy, and short strategy will encourage the learners more actively involved in learning.

Step 2: Related instruction Selection for learning; the material being available, Up-to-date, relevant to the learning sub-session (these may include, videos, text reading,

Podcasts and screencasts or presentations etc.

Step 3: Assessment and Evaluations for verifying the learning outcome of each session

The evaluation can be conducted by using various methods:

1. Quizzes

2. Live discussions

3. Concept mapping/mind mappings/word mappings reviews-reinforcing -a great learning

4. Critical Report writing skills

5. Reading Skills

Step 4: Review-back to face-to-face activities; implementing collaborative and interactive activities in group, and solo modes of peer's activities.

Role of teacher can be defined in Flip classroom approach upwards in respect of factors.

- An Activator

- Feedback provider

- Supporter with respect to individuals in learning
- Manager in all activities

- Motivator

- Analyzer the all activities

Flipped Classroom is different or same as Flipped Learning:

Sometimes, the flipped classroom[28] referred as inverted shall not be the flip learning, its pertaining to the classroom environments and activities happening around there, whereas actual Flipped class is like more individualized exposure of the learner. Learners free to move their own pace, time, and place.

Learners may have to see the routine practice the following in the Flipped Classroom

1. Enhance the Skill practice, under supervision of teacher

2. Face-to-Face mode for interactive role - discussion with peers

3. Open progressive and collective detailed Debate on given topic

4. Defending arguments and concluding with Presentations 5. Station learning by switching off-class activities and roles 6. Lab experiments Flipping in hybrid mode

7. Evaluation by Peer assessment and reviewing the feedback of homework.

Flipped cultures in flipped classroom learning patterns:

1. Pre-Classroom flip approach: homework activity before commencing of class-face-to-face

2. Post-classroom flip approach: homework activity after the commencing of class- face-to-face

3. Hybrid-class flip approach: rotationally flipping, both approaches.

\section{Pre-classroom Flipped approach:}

The concept of this is that sharing content of the lecture and getting involved for some clarification so that no any confusion remained about the topics, and when they come to class physically, be prepared for any further innovative conclusions and concepts. This may also further divide into active (interactive) and passive (non-interactive).

1. Active concept is like online when students get interact lively for not only with teacher but as well as groups for further information and understandings, collaboratively.

2. Passive concepts such like a way of getting the lecture contents uploaded/repository for study before getting into the class, no interactive case before commencing of classes physically.

\section{Post-classroom flipped approach}

This may also divide into active (interactive) and passive (non- interactive)

1. Active post-class flip, after commencing of class some queries of students may have remain in mind so on fixed schedule time for flip classroom schedule, meet up on the time for interactive mode lively. Further teacher may examine, take quizzes, and respond them online, students also share their info with groups for collaborative study. 
Anwar Ali Sathio et al., International Journal of Emerging Trends in Engineering Research, 9(7), July 2021, 973 - 982

2. Passive post-class flip, in this approach after class lecture some questions, queries may be forwarded to teacher by sources and after study he will prepare a proper reply and students may share and discuss it GroupWise.

\section{Practical theories in Flipped classroom:}

1. Dr Lawrence [46,47,75,76] proposed model of Flipped classroom, being sensible learners, give feedback smoothly, played well with vital performance. .

2. According to [25], decreasing the ole of teacher, freeing the learner to get what ways he may see feasible to him shifting conventional pedagogy to engineering patterns. Goh in 2013[26] observed the wealthy and positive environments for desired goals and objectives can be achieved.

\section{Krienan Flipped Classroom model}

According to [41], he additionally, modules added and also with additional features of flipped classrooms to enhance the reachability and flexibility of regular and private candidates shall be implicitly part and parcel in the model.

\section{Holistic Flipped space Model}

According to[12,77,78] exposed the composition of the flipped concepts by Progressive Activities, collaborating Experiences, and heterogeneous Platforms, extending it into four structures of flipped space approach like Flexible Environments, Learning Culture, Intentional Content, and practiced Educators and intentional holistic Flipped space (HFC) model. Holistic Flipped space is also a concept of total of home, mobile and physical appearance of learners synchronously.

\section{REFERENCES}

1. Bryan and K. N. Volchenkova, "Blended Learning: Definition, Models, Implications for Higher Education," Bull. South Ural State Univ. Ser. "Education. Educ. Sci., vol. 8, no. 2, pp. 24-30, 2016, doi: 10.14529/ped160204.

2. Evseeva and A. Solozhenko, "Use of Flipped Classroom Technology in Language Learning," Procedia - Soc. Behav. Sci., vol. 206, no. November, pp. 205-209, 2015, doi: 10.1016/j.sbspro.2015.10.006.

3. Angelo, T. (2012). Designing subjects for learning: practical, research-based principles and guidelines. In L. Hunt \& Ash, K. (2012). Educators view "flipped" model with a more critical eye. Education Week, 32(2), S6-S7.

4. A. Brown, "Understanding the Flipped Classroom : Types, Uses and Reactions to a Modern and Evolving Pedagogy," Culminating Proj. Teach. Dev., no. 12, p. 27, 2016, [Online]. Available:http://repository.stcloudstate.edu/cgi/viewcontent. cgi?article $=1010 \&$ context $=$ ed_etds.

5. Baker, J. W. (2000). The "Classroom Flip", Using web course management tools to become the guide by the side.

6. Bergmann, J., \& Sams, A. (2012). Flip your classroom: Reach every student in every class every day. Eugene, OR: International Society for Technology in Education

7. Birgili, B., Seggie, F.N. \& Oğuz, E. The trends and outcomes of flipped learning research between 2012 and
2018: A descriptive content analysis. J. Comput. Educ. (2021). https://doi.org/10.1007/s40692-021-00183-y

8. Bishop, J. L., \& Verleger, M.A. (2013). The flipped classroom: A survey of the Research.120th ASEE Annual Conference and Exposition. Atlanta, American Society for Engineering Education. References Page | 104

9. Boyer, A. (2013). The flipped classroom. Catering for difference. Teacher Learning Network. 20 (1), 28-29. Retrieved 23 $3^{\text {rd }} \quad$ March 2021 from http://teacherlearningnetwork.org.au/dl65/TLN-issue1_2013 sm.pdf

10. Educause (2012). Things you should know about flipped classrooms. Retrieved $23^{\text {rd }}$ March 2021, from http://net.educause.edu/ir/library/pdf/eli7081.pdf

11. Brame, C. J. (2012). Flipping the classroom. Vanderbilt University Center for Teaching. Retrieved, $23^{\text {rd }}$ March 2021 fromhttp://cft.vanderbilt.edu/files/Flipping-the-classroom.pd $\mathrm{f}$

12. Chen, Y., Wang, Y., Kinshuk, \& Chen, N. S. (2014). Is FLIP enough? or should we use the FLIPPED model instead? Computers and Education, 79, 16-27.

13. Collins, J. W., \& O'Brien, N. P. (2011). The Greenwood dictionary of education. ABC-CLIO

14. Chalmers (Eds), University teaching in focus: a learning-centred approach (pp. 93-111). Melbourne: ACER Press.

15. Dziuban, C., Moskal, P., \& Hartman, J. (2005). Higher education, blended learning, and the generations: Knowledge is power: No more. Elements of quality online education: Engaging communities. Needham, MA: Sloan Center for Online Education.

16. Educause (2012). 7 things you should know about flipped classrooms. Retrieved, 23 ${ }^{\text {rd }}$ March 2021 fromhttps://library.educause.edu/resources/2012/2/7-thingsyou-should-know-aboutflipped-classrooms

17. Enfield, J. (2013). Looking at the impact of the flipped classroom model of instruction on undergraduate multimedia students at CSUN. TechTrends, 57(6), 14-27

18. F. Morgans, "Blending and flipping learning: a journey in innovative curriculum design and delivery: a case study exploring teachers' understandings and perceptions of blended, flipped learning," [Online]. Available: https://mro.massey.ac.nz/bitstream/handle/10179/11430/01_ front.pdf?sequence $=1 \&$ isAllowed $=\mathrm{y}$.

19. Findlay-Thompson, S., \& Mombourquette, P. (2014). Evaluation of a flipped classroom in an undergraduate business course. Business Education \& Accreditation, 6(1), 63-71.

20. Flipped Learning Network. (2014). The four pillars of F-L-I-P. Retrieved, 23 ${ }^{\text {rd }}$ March 2021 from www.flippedlearning.org/definition.

21. Friesen M. Report: Defining Blended Learning. Available 
Anwar Ali Sathio et al., International Journal of Emerging Trends in Engineering Research, 9(7), July 2021, 973 - 982

http://blogs.ubc.ca/nfriesen/2012/09/01/where-does-blendedendvirtual-begin/ (accessed $23^{\text {rd }}$ March 2021)

22. Fulton, K. (2012). The Flipped Classroom: Transforming Education at Byron High School: A Minnesota High School with Severe Budget Constraints Enlisted YouTube in ItsSuccessful Effort to Boost Math Competency Scores.THE Journal (Technological Horizons in Education), 39(3), 18.

23. G. Saliba, L. Rankine, and H. Cortez, "The Fundamentals of Blended Learning," Univ. West. Sydney, p. 38, 2013, [Online]. Available: http://scholar.google.com/scholar?hl=en \&btnG=Search\&q=i ntitle:Fundamentals+of+Blended+Learning\#4.

24. Gallini, J. K., \& Barron, D. (2001). Participants' perceptions of web-infused environments: A survey of teaching beliefs, learning approaches, and communication. Journal of research on technology in education, 34(2), $139-156$

25. Goh, S., Chochrane, S., \& Brodie, L. (2012). The impact on values and learning behaviours of engineering students from an authentic learning environment: Preliminary analysis and observations. Proceedings of the 2012 AAEE Conference, Melbourne, Victoria. 3-5 December

26. Goh, S., Sankey, M. (2013). Authentic learning in Steven Goh's flipped classroom. Retrieved $23^{\text {rd }}$ March 2021, from https://vimeo.com/68278046

27. Gonzalez, J. (2014). Modifying the flipped classroom:

The "in-class" version. Retrieved, 23rd March,2021 fromhttp://www.edutopia.org/blog/flipped-classr oom-in-class-version-jennifer-gonzalez.

28. Goodwin, B., \& Miller, K. (2013). Evidence on flipped classrooms is still coming in. Educational Leadership, 70(6), 78-80.

29. Graham C.R. Blended Learning Systems: Definition, Current Trends, and Future Directions. The Handbook of Blended Learning: Global Perspectives, Local Designs. San Francisco, Pfeiffer Publ., 2006, pp. 3-21

30. Grant, C. (2013). First inversion: a rationale for implementing the 'flipped approach' in tertiary music courses. Australian Journal of Music Education.

31. Hamdan, N., McKnight, P., McKnight, K., \& Arfstrom, K. M. (2013). A review of flipped learning. Flipped Learning Network. Retrieved, 23 ${ }^{\text {rd }}$ March 2021 from http://www.flippedlearning.org/

cms/lib07/VA01923112/Centricity/Domain/41/LitReview_F lippedLearning.pdf.

32. Hamdan, N., McKnight, P., McKnight, K., \& Arfstrom, K. M. (2013). The flipped learning model: A white paper based on the literature review titled A Review of Flipped Learning.

33. Herreid, Clyde Freeman. - Schiller, Nancy A. (2013).

"Case studies and the flipped classroom." Journal of College Science Teaching, 42(5), 62-66. Jenkins, C. The Advantages and Disadvantages of the Flipped Classroom.
http://info.lecturetools.com/blog/bid/59158/The-Advantages -and-Disadvantages-of-the-Flipped-Classroom. Erişim tarihi, 12 Eylül 2016

34. Hess, G.F. 2013. Blended courses in Law School: The best of online and face-to-face learning? McGeorge Law Review, 45: 51-84.

35. Hirsch, J. (2014). "Fliperentiated" instruction: How to create the customizable classroom. Edutopia. Retrieved, $23^{\text {rd }}$ March,2021,from,http://www.edutopia.org/blog/fliperentiate d-instruction-createcustomizable-classroom-joe-hirsch.

36. Johnson, L., \& Adams, S. ,2011). Technology Outlook for UK Tertiary Education 2011-2016: An NMC Horizon Report Regional Analysis. New Media Consortium.

37. Johnson, L., Adams Becker, S., Estrada, V., \& Freeman, A. (2015). NMC horizon report: 2015 higher education edition. Austin, TX: The New Media Consortium. Retrieved, $23^{\text {rd }}$,March,2021, from,http://cdn.nmc.org/media/2015-nmchorizon-report-HE-EN.pdf

38. Johnson, L., Becker, S., Estrada, V., \& Freeman, A. (2014). Horizon Report: 2014 Higher Education

39. Kara, C.O. (2016). Tıp Fakültesi Klinik Eğitiminde "Ters Yüz Sınıf Modeli” Kullanılabilir Mi? Yüksek lisans Tezi. Akdeniz Üniversitesi, Sağlık Bilimleri Enstitüsü, Antalya

40. Karadeniz, A. (2015). Ters-Yüz Edilmiş Sınıflar. Eğitim ve Öğretim Araştırmaları Dergisi. Ağustos 2015 Cilt:4 Sayı:3 Makale No: 35 ISSN: 2146-9199.

41. Kiernan, E., Sankey, M. (2013). Helping first year student's transition to study by using a flipped classroom. Available online at: https://soundcloud.com/michael-sankey/ellies-flipped-classr oom

42. Kim, M. K., Kim, S. M., Khera, O., \& Getman, J. (2014). The experience of three flipped classrooms in an urban university: an exploration of design principles. Internet and Higher Education, 22, 37-50.

43. Knewton.com. (2011). The Flipped Classroom Infographic,[url:http://www.knewton.com/flipped-classroom /]. Erişim Tarihi 12 Eylül 2016

44. Krasnova T. A Paradigm Shift: Blended Learning Integration in Russian Higher Education. Procedia - Social and Behavioral Sciences, 2015, no. 166, pp. 399-403. DOI: 10.1016/j.sbspro.2014.12.543

45. Lage, M. J., Platt, G., \& Treglia, M. (2000). Inverting the classroom, A gateway to creating an inclusive learning environment. Journal of Economic Education, 31(1), 30-43. doi, 10.2307/1183338 from http, //www.innosightinstitute.org/innosight/wpcontent/ uploads/2012/05/Classifying-K-12-blended-learning2. pdf. Erişim tarihi, 11 Eylül 2016

46. Lawrence, J. (2013). Designing and evaluating an empowering online pedagogy for commencing students: a 
Anwar Ali Sathio et al., International Journal of Emerging Trends in Engineering Research, 9(7), July 2021, 973 - 982

case study. The International First Year in Higher Education Conference 2013, Wellington, New Zealand, 7 -10 July.

47. Lawrence, J., \& Sankey, M. (2013). Promoting academic skills development through the flipped classroom. Available online at: https://vimeo.com/67391452

48. M. J. Kintu, C. Zhu, and E. Kagambe, "Blended learning effectiveness: the relationship between student characteristics, design features and outcomes," Int. J. Educ. Technol. High. Educ., vol. 14, no. 1, 2017, doi: 10s.1186/s41239-017-0043-4.

49. Meyer, K. A. (2003). Face-to-face versus threaded discussions: The role of time and higher order thinking. Journal of Asynchronous Learning Networks, 7(3), 55-65 50. Miller, A. (2012). Five best practices for the flipped classroom. Edutopia, 24, 02-12.

51. Napier, N. P., Dekhane, S., \& Smith, S. (2011). Transitioning to Blended Learning: Understanding Student and Faculty Perceptions. Journal of Asynchronous Learning Networks, 15(1), 20-32.

52. Oliver, M., \& Trigwell, K. (2005). Can 'blended learning' be redeemed?. E-learning and Digital Media, 2(1), 17-26.

53. Pluta, W. J., Richards, B. F., \& Mutnick, A. (2013). PBL and beyond: Trends in collaborative learning. Teaching and learning in medicine, 25(sup1), S9-S16.

54. Procter C.T. Blended Learning in Practice. Available at: www.ece.salford.ac.uk/proceedings/ papers/cp_03.rtf (accessed 23 ${ }^{\text {rd }}$ March 2021)

55. Project Tomorrow, Flipped Learning Network. (2014). Speak up 2013 national research project findings: A second year review of flipped learning. Flipped Learning Network, Project Tomorrow. Retrieved,23 ${ }^{\text {rd }}$ March 2021 from http://www.flippedlearning.org/cms/lib07/A01923112/Centr icity/Domain/41/Speak\%20Up\%202013\%20Survey\%20Res ults\%20F lipped\%20Learning\%20Network.pdf

56. Ravenscroft, B., \& Luhanga, U. (2014, June). Developing Employability Skills in Humanities and Social Sciences Using the Flipped Model. In ICEL2104-Proceedings of the 9th International Conference on e-Learning: ICEL 2014(p. 142). Academic Conferences Limited. Review, In The Third International Conference on E-Learning and E-Technologies in Education

57. Roehl, A., Reddy, S. L., \& Shannon, G. J. (2013). The flipped classroom: An opportunity to engage millennial students through active learning strategies.Journal of Family \& Consumer Sciences, 105(2), 44-49.

58. Ş. Uluçınar Sağır and D. Sakar, "Flipped classroom model in education,” Int. J. Soc. Sci. Educ. Res., vol. 3, no. 5 S, pp. 1904-1916, 2017, doi: 10.24289/ijsser.348068.

59. Shibley, I. (2009) Online classroom. Blended and flipped: Exploring new models of effective teaching and learning.Magna Publication.

60. Staker H., Horn M.B. Classifying K-12Blended Learning. Available at: http://www. christenseninstitute.org/wp-content/uploads/2013/ 04/Classifying-K-12-blended-learning.pdf (accessed $23^{\text {rd }}$ March 2021)

61. Strayer, J. F. (2007). The effects of the classroom flip on the learning environment: A comparison of learning activity in a traditional classroom and a flip classroom that used an intelligent tutoring system (Doctoral dissertation, The Ohio State University).

62. T. D. Baruah, "Effectiveness of Social Media as a tool of communication and its potential for technology enabled connections: A micro-level study," Int. J. Sci. Res. Publ., vol. 2, no. 5, pp. 1-10, 2012, doi: ISSN 2250-3153.s

63. Talbert, Robert. (2012). "Inverted classroom." Colleagues, 9(1), 7. Tezci, E., ve Perkmen, S. (2013). Oluşturmacı perspektiften teknolojinin öğrenme-öğretme sürecine entegrasyonu. Çağıltay, K. ve Göktaş, Y. (Ed.). Öğretim teknolojilerinin temelleri: Teoriler, araştırmalar, eğilimler (s.185- 211). Ankara Turkey: PEGEM.

64. Turan. Z. (2015). The evaluation of flipped classroom method and examination of its effects on academic achievement, cognitive load and motivation. Doktora Tezi Atatürk Üniversitesi Eğitim Bilimleri Enstitüsü, Erzurum.

65. Valiathan P. Blended Learning Models. Available at: http://purnima-valiathan.com/

wpcontent/uploads/2015/09/Blended-LearningModels-2002ASTD.pdf (accessed 23 ${ }^{\text {rd }}$ March 2021)

66. Watson J., Murin A. A History of K-12 Online and Blended Instruction in the United States. Handbook of Research on K-12 Online and Blended Learning. N.P., ETC Press Publ., 2014, pp. 1-24.

67. Wells, M., \& Holland, C. (2016). Flipping Learning! Challenges in Deploying Online Resources to Flipped Learning in Higher Education. In J. Keengwe, \& G. Onchwari (Eds.) Handbook of Research on Active Learning and the Flipped Classroom Model in the Digital Age (pp. 1-18). Hershey, PA: . doi:10.4018/978-1-4666-9680-8.ch001 68. Wheeler, S. (2015). Learning with 'e"s. Wales, UK, Crown House.

69. Z. SEKAR, "Blended Learning vs. Flipped Classroom: Strengths and Challenges," Researchgate.Net, no. April 2017, 2019, [Online]. Available: https://www.researchgate.net/profile/John_Jeyaraj/publicatio n/337154969_Blended_Learning_vs_Flipped_Classroom_St rengths_and_Weaknesses/links/5dc85060a6fdcc57503dd784 /Blended-Learning-vs-Flipped-Classroom-Strengths-and-We aknesses.pdf.

70. Zheng, M., Chu, C.-C., Wu, Y., \& Gou, W. (2018). The Mapping of On-Line Learning to Flipped Classroom: Small Private Online Course. Sustainability, 10(3), 748. MDPI AG. Retrieved, $23^{\text {rd }} \quad$ March 2021 from http://dx.doi.org/10.3390/su10030748

71. Waseem, Mohammad, Abdullah Lakhan, and Irfan Ali Jamali. "Data security of mobile cloud computing on cloud server." Open Access Library Journal 3.4 (2016): 1-11. 
72. Lakhan, Abdullah, et al. "Deep neural network-based application partitioning and scheduling for hospitals and medical enterprises using IoT assisted mobile fog cloud." Enterprise Information Systems (2021): 1-23.

73. Lakhan, Abdullah, and Xiaoping Li. "Transient fault aware application partitioning computational offloading algorithm in microservices based mobile cloudlet networks." Computing 102.1 (2020): 105-139.

74. Lakhan, Abdullah, et al. "Mobility aware blockchain enabled offloading and scheduling in vehicular fog cloud computing." IEEE Transactions on Intelligent Transportation Systems (2021).

75. Lakhan, Abdullah, and Xiaoping Li. "Content aware task scheduling framework for mobile workflow applications in heterogeneous Mobile-Edge-Cloud paradigms: CATSA framework." 2019 IEEE Intl Conf on Parallel \& Distributed Processing with Applications, Big Data \& Cloud Computing, Sustainable Computing \& Communications, Social Computing \& Networking (ISPA/BDCloud/SocialCom/SustainCom). IEEE, 2019.

76. Lakhan, Abdullah, and Li Xiaoping. "Energy aware dynamic workflow application partitioning and task scheduling in heterogeneous mobile cloud network." 2018 International Conference on Cloud Computing, Big Data and Blockchain (ICCBB). IEEE, 2018.

77. Lakhan, Abdullah, and Xiaoping Li. "Mobility and fault aware adaptive task offloading in heterogeneous mobile cloud environments." EAI Endorsed Transactions on Mobile Communications and Applications 5.16 (2019).

78. Lakhan, Abdullah, et al. "Smart-Contract Aware Ethereum and Client-Fog-Cloud Healthcare System." Sensors 21.12 (2021): 4093.

79. Lakhan, Abdullah, et al. "Delay sensitive application partitioning and task scheduling in mobile edge cloud prototyping." International Conference on 5G for Ubiquitous Connectivity. Springer, Cham, 2018.

80. Lakhan, Abdullah, Syed Imran Ali, and Asra Memon. "Secure Data Storage in Mobile Cloud Computing." 